值と比較したところ約 2 倍の值を示した。よって本実験 では1/2倍にした值を使用した。抜け時間，硫化ソーダ法 により，約 $15 \mathrm{~g} / \ell$ を超えなければ，90秒自現機において 定着主薬の消費などの心配はないと思われる。銀濃度の 測定範囲が， $0 \sim 30 \mathrm{~g} / \ell, \mathrm{pH} 4$ 〜 6゙らいを細かく測定 できれば，定着液の管理面でより有用と思われる。

322. 定着液の疲労度が写真濃度に及ぼす影響について (第一報)

福島県立医科大学附属病院放射線科

○青山正勝・遊佐 烈・半田信人

樋口義典・佐藤孝則・片倉俊彦

伊藤正已 ・上田 稔

自現機において定着液槽内に持込む現像液が定着を疲 労させる.CRT フィルムと直接フィルムのコントロール ピース, 腹部 CT 写真を同時現像し疲労度が写真濃度に 及ぼす影響と, 容認度について検討をした。定着新液に 現像液を $0 \%$ から $30 \%$ 迄混入し, コントロールピースの 濃度特性曲線を求めた。また, 腹部 CT 写真の肝, 腎の 正常部とチスト部をマイクロデンシトメータで計測し, 混入率による変化をみた。その結果として定着液の疲労 度が写真濃度に関与している.CRTフィルムにおいて肩 部より $\mathrm{D}_{\mathrm{MAx}}$ にかけての変化が写真全体をフラットにし， シャウカステンの輝度により病巣等の判別が困難となる。 混入率の割合が10\%以内であれば，写真濃度に影響がで にくいことが判った。

323. 現像液の色調変化と活性度について（マンセル表色 系による液管理）第 1 報

神戸大学医学部附属病院中央放射線部

○古東正宜・小寺滋子 ・ 岡山貴宣

今井方丈・松永 登・北山卓弘

小西六写真工業(侏)

岡田敏正

〔目的〕現像液の活性度を定量的に把握する目的で, マンセル表色系を利用し, 現像液の色調変化とその活性 度について検討した。

〔方法〕(1)現像液の空気酸化による着色変化と, マン セル表色系を対比させた。（スターラ使用)(2)現像液の着 色変化と写真特性との相関を求めた. (センシトメー夕使 用，手現像）(3)自現機通常使用でのランニングによる現 像液の着色変化と写真特性の対比を行った。

〔結果〕（1)マンセル表色系を用いることにより，着色 の数値化表示が可能となった。(2)現像液の着色は, 空気 酸化の影響が大きい. (3)現像液の活性度に関し，色調変 化をマンセル表示することにより，色調変化による自現
機の品質管理が可能となるであろう。

\section{4. 簡単な定着液中の銀定量法}

近畿大学ライフサイエンス研究所

○山本義憲

近畿大学医学部

浅香征洋

近畿大学医学部附属病院中央放射線部

美甘美嘉子

西宮市立中央病院中央放射線部

田辺康治・諏訪田智敬・森本治男

安田火災海上保険KK大阪診療所

津山泰子

定着液と $\mathrm{H}_{2} \mathrm{O}_{2}$ を反応させると, $\mathrm{Ag}_{2} \mathrm{~S}$ と $\mathrm{AgBr}$ が生 成し沈澱する。(急激な反応で注意を要する)この反応 は, 競合反応で化合物に含まれる, $\mathrm{Ag}_{2} \mathrm{~S}$ と $\mathrm{AgBr}$ の比率 は, 周囲温度, 添加速度によって変化する. 反応時の条 件, 温度 $25^{\circ} \mathrm{C} \sim 27^{\circ} \mathrm{C}$, 定着液と同量の $\mathrm{H}_{2} \mathrm{O}_{2}(30 \%)$ 急速 添加で $\mathrm{Ag}_{2} \mathrm{~S} \mathrm{10 \% ,AgBr} 90 \%$ と一定の值を示す.したが って，生成した化合物の $60 \%$ 銀量とすれば，フォルハ ルト法との詥差，5\%以内の精度で測定可能である．簡 便には，半定量試験紙と化合物の力サ（高，低）により， 相対的な目安值を知ることができる。フィルムは，省銀 化設計がなされており，銀量を測定して適正な管理を行 い，補充量など，省資源化を計るべきと考える.

325. X 線撮影系における乾式現像（dry silver）の適用 について（第 1 報 その原理と基礎実験）

国立循環器病センター放射線診療部

○片㴊哲朗・若松孝司

内田英治・東儀英明

現在 X 線フィルムのほとんどは湿式現像によって行 われているが，われわれは新しい感光材料の現像法とし て熱による乾式現像を試みた。これは $3 \mathrm{M}$ 社が開発した dry silver と呼ばれるもので，今回はこの熱現像の原理 とその一部を X 線撮影系に応用した.その結果, I.I. 撮影 系においては感度等の問題があるが，絞りや撮影条件に よっては撮影可能であった。また CT, DSA などの CRT フィルムには早期害用可能であると思われる。しかしこ れらを一般スクリーン系に適用するのは現段階において 難しい.このシステムは多くの改良の余地は残っている が，将来的には実現性が高い。これら乾式現像が臨床的 に使用されるようになれば，X 線撮影系は新たな変革期 をむかえるものであろうと考えている。

\section{座長集約}

このセクションは現像管理に関する演題群で，3 題は 